\title{
Entre el edén y la barranca. La dimensión mágica y trágica de Under the Volcano
}

Jorge ALCÁZAR

Universidad Nacional Autónoma de México

Antes de adentrarnos en la singular novela de Malcolm Lowry, tal vez sería conveniente plantear un parámetro de referencia que nos permita sopesar mejor el valor de esta obra. De entrada, podemos afirmar que Under the Volcano (1947) es una de las pocas novelas, de habla inglesa, que ha asimilado las estrategias narrativas y el grado de complejidad estructural del opus magnum de Joyce: Ulysses (1922). Según sabemos por los esquemas que el autor le proporcionó a Carlo Linati, cada capítulo de Ulysses presenta un paralelo homérico con la Odisea, despliega una técnica narrativa especial, cubre una determinada hora del 16 de junio de 1904, y guarda relación con un órgano del cuerpo, una disciplina, un color, así como un simbolismo particular. Este intrincado esquema después pasaría por las manos de Valéry Larbaud (divulgador de la obra de Joyce), Jacques Benoîst-Méchin (traductor de "Penelope"), Silvia Beach (editora de la novela) y otros que prometieron guardar tan celoso secreto, hasta que fue incorporado a las páginas del estudio James Joyce's Ulysses (1931), de Stuart Gilbert - quien también fue asesorado por el propio novelista irlandés-, y convertirse en la interpretación canónica de la novela. $^{1}$

Ambición semejante a la de Joyce es la que exsuda la carta a Jonathan Cape, que Lowry envió a su editor a principios de 1946. Esta carta se puede considerar como un metatexto apologético, en el que el autor pormenoriza los principios estructurales y simbólicos que sustentan su obra. En ella trata de contrarrestar el juicio negativo del dictaminador de la casa editora - que ahora se sabe fue William Plomer-y, por ende, la amenaza palpable de mutilar o abreviar algunas partes de la novela.

Si Ulysses transcurre en unas dieciocho horas y tiene dieciocho capitulos - sin número o título- protagonizados por tres personajes: Stephen Dedalus, Leopold Bloom y su esposa Molly, la novela de Lowry nos presenta doce ca-

1 Richard Ellmann, James Joyce. Nueva York, Oxford University Press, 1959, pp. 514-515, 533-536, 629. 
pítulos numerados, que abarcan los sucesos del 2 de noviembre de 1938, en los que están involucrados el ex cónsul inglés Geoffrey Firmin (un dipsómano irredento), su esposa Yvonne (que vuelve después de haberlo abandonado) y su mediohermano Hugh (un soñador revolucionario, de quien más tarde se sabe tuvo un amorío con ella).

Al novelista le llevó varias páginas de la carta enviada a Cape para justificar y defender la integridad orgánica del libro y sus diversos planos y niveles de lectura. Entre las cosas que plantea se encuentra el valor especial -casi mágico podría decirse, en un hombre que otorgaba una trascendencia inusitada a los encuentros fortuitos y las coincidencias - que le asigna al número doce, como si estuviese imbuido de la mentalidad analógica-libresca, herencia del medievo y el renacimiento donde todas las partes del cosmos encuentran su contraparte y su correspondencia.

The twelve chapters should be considered as twelve blocks [...] Each chapter is a unity in itself and all are related and interrelated. Twelve is a universal unit. To say nothing of the 12 labours of Hercules, there are 12 hours in a day, and the book is concerned with a single day as well as, though very incidentally, with time: there are 12 months in a year, and the novel is enclosed by a year; while the buried layer of the novel or poem that attaches itself to myth, does so to the Jewish Cabbala where the number 12 is of the highest symbolic importance. ${ }^{2}$

Bien se puede dudar de esto ya que no hay elementos, dentro del contexto numerológico de la cábala, para justificar semejante aseveración; sin embargo, tal vez más tarde se podrá entender el marco conceptual de donde proviene. Lo que vale la pena subrayar, por el momento, es que Lowry trata de darle un sustrato mágico al mundo del Cónsul, a quien delinea como una especie de Fausto moderno, y esto también le da pie para asociarlo con el número doce: "it is as if I hear a clock slowly striking midnight for Faust; as I think of the slow progression of the chapters, I feel it destined to have 12 chapters and nothing more nor less will satisfy me". ${ }^{3}$ Asimismo, la docena numérica recubre la forma circular de la novela que comienza donde termina, y que el autor concebía como una rueda con doce rayos que haría que el lector atento y cuidadoso quisiera volver al principio. Entre la acción y la reacción de estos motivos: el giro de la rueda y el descenso trágico, se despliega el núcleo temático de la novela como se verá más adelante.

${ }^{2}$ Harvey BREIT y Margerie BONNER LOWRY, eds., Selected Letters of Malcom Lowry. Harmondsworth, Penguin, 1985, p. 65.

${ }^{3}$ Ibid., pp. 65-66. 
El capítulo inicial tiene lugar exactamente un año después, y está focalizado en Jacques Laruelle - un cineasta amigo de Firmin y también ex amante de Yvonne-, quien, tras un partido de tenis, regresa a su casa por las tortuosas calles de Quauhnahuac, dispuesto a dejar el lugar para siempre. Al igual que en Nostromo, otro portento de organización novelesca, aparecen los sitios y las imágenes clave de ese Día de Muertos: la ciudad con sus cincuenta y siete cantinas, los fantasmas de Carlota y Maximiliano, la pareja de volcanes aterradores, el jardín adánico, la barranca, la rueda de la fortuna, una película suspendida (Las manos de Orlac), un libro olvidado, una carta que nunca se mandó, la partida inminente, el recuerdo del cónsul; y a todo esto lo permea el paisaje mexicano que bien pareciera pertenecer a otro planeta: "there was no denying its beauty, fatal or cleansing as it happened to be, the beauty of the Earthly Paradise itself". ${ }^{4}$ Entre las cosas que recuerda Laruelle, al recibir el volumen olvidado de tragedias isabelinas que se vuelve el signo emblemático de lo que no se puede regresar, está la idea que algún día tuvo: "of making in France a modern film version of the Faustus story with some such character as Trotsky for its protagonist". ${ }^{5} \mathrm{Ya}$ antes el mismo cónsul le había sugerido que hiciera una película sobre la Atlántida, que Geoffrey asociaba con "the spirit of the abyss, the god of storm, 'huracán'", al pasar por la barranca, por el puente que él mismo ha cruzado esa tarde. Vale la pena detenerse en este pasaje para ver cómo funciona la estrategia de Lowry de acumular símbolos.

The Ferris wheel came into view again, just the top, silently burning high on the hill, almost directly in front of him, then the trees rose over it. The road, which was terrible and full of pot-holes, went steeply downhill here; he was approaching the little bridge over the barran$c a$, the deep ravine. [...] It was too dark to see the bottom, but: here was finality indeed, and cleavage! Quauhnahuac was like the times in this respect, wherever you turned the abyss was waiting for you round the corner. Dormitory for vultures and city Moloch! When Christ was being crucified, so ran the sea-borne, hieratic legend, the earth had opened all this country, though the coincidence could hardly have impressed anyone then $!^{6}$

Aquí encontramos la primera de una serie de imágenes equivalentes que se asocian con la trayectoria descendente que le está reservada al Cónsul, entre las cuales se pueden mencionar: "The Hell Bunker" (la trampa de arena en el

\footnotetext{
${ }^{4}$ Malcolm LowRY, Under the Volcano. Harmondsworth, Penguin, 1977, p. 16.

${ }^{5}$ Ibid., p. 33.

${ }^{6}$ Ibid., p. 21.
} 
campo de golf) de los años juveniles (cap. 1); el armadillo que cava su camino subterráneo y arrastra a quien trata de salvarlo (cap. 4); la cañada en el jardín de la casa de la calle Nicaragua (cap. 5); "The Golgotha Hole", del capitulo 7, que el cónsul termina por asociar con "Golf = gouffre = gulf"; ${ }^{7}$ la barranca de la historia de los pueblos indefensos, que aparece en la discusión que tiene, al calor de las copas, con Hugh (cap. 10), y - por último- la cañada donde los sinarquistas arrojan su cuerpo (cap. 12). Todas estas imágenes sugieren la caída en el abismo, pero también el camino del sacrificio que redime. ¿Qué significa la muerte de un borrachín don nadie en un pais extranjero, en momentos en que se ciernen las manos sombrías y ensangrentadas del fascismo y la intolerancia, en tiempos en los cuales el heroísmo trágico es cuestión del pasado? George Steiner ha señalado la imposibilidad y la muerte de la tragedia en el mundo moderno, donde los mitos tutelares que podian sustentar a un Sófocles o a un Shakespeare han desaparecido. Y esto está implícito en el gesto anónimo de Firmin cuando, al final de la novela, se enfrenta en su delirio a los Jefes de Jardineros y Rostrums. Sin embargo, el alcance de tal actitud se insinúa desde el principio de la obra, cuando Jacques rememora:

What had happened just a year ago today seemed already to belong in a different age. One would have thought the horrors of the present would have swallowed it up like a drop of water. It was not so. Though tragedy was in the process of becoming unreal and meaningless it seemed one was still permitted to remember the days when an individual life held some value and was not a mere misprint in a communiqué. ${ }^{8}$

Lo que ahora debemos plantearnos es de qué manera Lowry trató de darle sustancia y estatura trágica a un protagonista que parece vagar perdido - como en el soneto de Baudelaire- en un bosque de símbolos que no logra descifrar. Para responder a esta pregunta debemos asomarnos un poco al proceso de composición de la novela. En la primavera de 1942, cuando Lowry se encontraba en Dollarton, trabajando sobre la cuarta versión de Under the Volcano, cayó en "la cuenta de que el cónsul era una especie de oficiante de magia negra, o de magia blanca que se había vuelto malo, y que Margerie debía traer de la Biblioteca de Vancouver lo que pudiese encontrar sobre alquimia y brujería". 9 Seguramente su esposa no encontró mucho. Pero días después conocieron a un extraño sujeto, Charles Stanfeld-Jones, que decía levantar censos y que resultó

${ }^{7}$ Ibid., p. 206.

${ }^{8}$ Ibid., p. 11.

9 Douglas DAY, Malcolm Lowry. Una biografia. México, FCE, 1983, p. 326. 
ser pupilo de Aleister Crowley, conocedor de materias ocultas y adepto de la cábala. Mediante las charlas y las lecciones que tuvo con él, Lowry terminó de plasmar el mundo intelectual del cónsul. Es así que, en su carta a Cape, afirma:

The Cabbala is used for poetical purposes because it represents man's spiritual aspiration. The Tree of Life, which is its emblem, is a kind of complicated ladder with Kether, or Light, at the top and an extremely unpleasent abyss some way above the middle. The Consul's spiritual domain in this regard is probably the Qliphoth, the world of shells and demons, represented by the Tree of Life upside down - all this is not important at all to the understanding of the book; I just mention it in passing to hint that, as Henry James says, "There are depths". ${ }^{10}$

A final de cuentas la metáfora del abismo tiene un afuera y un adentro, puesto que el descenso al fondo del abismo significa el enfrentamiento de Geoffrey Firmin con sus propios fantasmas, con sus culpas pasadas - como cuando era comandante del Samaritan - que lo equiparan con Lord Jim; los estados de incomunicación con Yvonne, y la tentación constante del alcohol con sus escasos momentos de lucidez, todo lo cual lo conduce al autoengaño y a hacer de su vida "a quixotic oral fiction". 11

En otro plano de lectura (y siguiendo las directrices de Lowry), el ámbito espiritual del cónsul sería análogo al "Qliphot". En la edición en español de la biografia de Douglas Day se añade una nota que transcribo en parte: "Kelifot (cáscaras), término cabalístico. Olam-ha-kelifot (el mundo de las cáscaras) se llama en la cábala la forma inferior o material de la vida". ${ }^{2}$ Esto nos remite a la mitología cabalista de la creación y a lo que se conoce como la ruptura de los vehículos o canales (en inglés, "the breaking of the vessels") de las emanaciones superiores, fenómeno también conocido como "la muerte de los reyes". Demos la palabra a una autoridad en la materia:

The vessels assigned to the upper three Sefirot managed to contain the light that flowed into them, but the light struck the six Sefirot from Hesed to Yesod all at once and so was too strong to be held by the individual vessels; one after another they broke, the pieces scattering and falling. The vessel of the Sefirah, Malkhut, also cracked but not to the same degree. Some of the light that had been in the vessels retraced its path to its source, but the rest was hurled down

\footnotetext{
${ }^{10} \mathrm{H}$. BREIT Y M. BONNER LOWRY, eds., op. cit., p. 65.

${ }^{11}$ M. LOWRY, op. cit., p. 39.

12 D. DAY, op. cit., p. 329.
} 
with the vessels themselves, and from their shards the kelippot, the dark forces of the sitra ahra ["the other side"], took on substance. These shards are also the source of gross matter. The irresistible pressure of the light in the vessels also caused every rank of worlds to descend from the place that had been assigned to it. The entire world process as we know it, therefore, is at variance with its originally intended order and position. Nothing, neither the light nor the vessels, remained in its proper place, and this development - called after a phrase borrowed from the Idrot of the Zohar, "the death of the primeval kings" - was nothing less than a cosmic catastrophe. ${ }^{13}$

Con esto en mente estaremos en condiciones de entender mejor lo que sucede en el capítulo cinco, cuando Geoffrey camina por el jardín de su casa $\mathrm{y}$, pensando en el Farolito en Parián, está a punto de caer en una barranca: "He paused, peeping, tequila-unafraid, over the bank. Ah the frightful cleft, the eternal horror of opposites! Thou mighty gulf, insatiate cormorant, deride me not, though I seem petulant to fall into thy chops". ${ }^{14}$ El gesto grandilocuente bien podría ser el de un Faustus ante las fauces del infierno. Asimismo, la selección léxica nos trae ecos de los dramas de Shakespeare. Por ejemplo, "insatiate cormorant" proviene de Richard II (II , i, 38), pero en Coriolanus podemos encontrar un pasaje más pertinente: "Should by the cormorant Belly be restrained, Who is the sink o' th' body" (I, i, 107-108).

Aquí "sink" se asocia con las funciones excretorias, lo cual está a tono con los pensamientos del cónsul que ve en el fondo de la cañada un riachuelo que sirve como drenaje:

One was, come to that, always stumbling upon the damned thing, this immense intrincate donga cutting right through the town, right, indeed, through the country, in places a two-hundred-foot sheer drop into what pretended to be a churlish river during the rainy season, but which, even now, though one couldn't see the bottom, was probably beginning to resume its normal role of general Tartarus and gigantic jakes. It was, perhaps, not so frightening here: one might even climb down, if one wished, by easy stages of course, and taking the occasional swig of tequila on the way, to visit the cloacal Prometheus who doubtless inhabited it. ${ }^{15}$

${ }^{13}$ Gershom SCHOLEM, Kabbalah. Nueva York, Meridian, 1978, pp. 138-139.

${ }^{14}$ M. LOWRY, op. cit., p. 134.

${ }^{15}$ Idem. 
A este Prometeo que alguna vez tuvo el fuego y la luz, y que ahora está condenado a la podredumbre, se le puede conectar con los kelippot cabalistas:

The broken vessels too, of course, were subjected to the process of tikkun or restoration which began immediately after the disaster, but their "dross" was unaffected, and from this waste matter, which can be compared to the necessary by-products of any organic process, the kelippot, in their strict sense as the powers of evil, emerged. ${ }^{16}$

Éste es uno de los modos en que se explica, en el contexto de la cábala, la aparición del mal.

En la novela, Geoffrey ya ha tenido la sensación de no pertenencia al malinterpretar el anuncio en el jardín público que colinda con su propiedad: "You like this garden? Why is it yours? We evict those who destroy! Simple words, simple and terrible words, words which one took to the very bottom of one's being". ${ }^{17}$ Poco antes, al buscar la botella de tequila en el jardín de su casa, se ha topado con una víbora - que ve como una rama y que en su estado de alucinación se transforma en un perro-, misma que más tarde asociará con Hugh.

Esta escena, en el entramado de la novela, es simultánea a la cabalgata bucólica de Hugh e Yvonne del capítulo anterior. Sin embargo, la belleza del paisaje, la tranquilidad del día, los planes de ir a Canadá, se ven empañados por una sensación de desasosiego. Hugh sabe que cualquier momento de felicidad como ese "will be poisoned as these moments are poisoned". ${ }^{18}$ Aqui encontramos figuras y símbolos semejantes: la barranca "the Malebolge"; una serpiente muerta en el camino; una pulquería de nombre La Sepultura, y referencias a Parián (el destino final del cónsul). A Hugh terminamos por asociarlo con Judas, la tentación y la traición, completándose así este triángulo repleto de alusiones bíblicas.

La estrategia empleada por Lowry es muy semejante a la que utiliza Joyce en Ulysses, donde Stephen Dedalus y Leopold Bloom, aun antes de conocerse, ya han sido hermanados espiritualmente a través de la acumulación de imágenes, símbolos y aun pensamientos parecidos. Baste un ejemplo, en capítulos separados - textualmente pero simultáneos en el tiempo de la novela - cada uno ve una nube, que resulta ser la misma, que los deprime: a Stephen le recuerda la madre fallecida y a Bloom la tierra baldía israelita. Ahora regresemos con el cónsul.

${ }^{16}$ G. SCHOLEM, op. cit., p. 139.

${ }^{17}$ M. LOWRY, op. cit., p. 132.

${ }^{18} \mathrm{Ibid}$., p. 111. 
Geoffrey Firmin ha desatendido las oportunidades que ha tenido este Día de Muertos de regenerarse, y una vez que se sube a la "máquina infernal" (capítulo 7) el giro de la fortuna será hacia abajo. En esa atracción mecánica de la feria, el Cónsul parece un Prometeo enjaulado que mira el mundo de cabeza y donde todo se le cae - hasta el pasaporte, signo de identidad--, prefigurando el descenso final bajo el volcán. Habría alguna similitud entre la posición de Firmin en la maquina infernal y el árbol de la vida invertido que menciona Lowry en su carta metatextual, y que de nuevo nos remite a la cábala.

Mas ahora cabría preguntarse qué tipo de cábala era la que Lowry conocía; seguramente no la de la mística judía que gradualmente hemos entendido gracias a los trabajos de Gershom Scholem o Moshe Idel, sino aquella que se inserta dentro de la tradición esotérico-sincrética que dominó la segunda mitad del siglo XIX con figuras como Eliphas Lévi o madame Blavastsky. Al respecto, Douglas Day, glosando a una estudiosa del tema, señala que:

Perle Epstein clasifica como una "corrupción" de la cábala original, es decir, que lo que Lowry estaba aprendiendo no era la "legítima" cábala de los sabios hebreos, derivada del Sefer Zohar [...] o del Sefer Yetzirah [...] sino una versión espuria llena de poses fin de siècle que conciernen al Tarot, la alquimia, los Rosacruces, los viajes astrales; en otras palabras, exactamente el tipo de invernáculo arcano que tanto había seducido a Yeats cincuenta años antes. ${ }^{19}$

En los tratados ocultistas del siglo pasado era común, y todavía lo es, crear correspondencias entre el alfabeto hebreo y los veintidós arcanos mayores del Tarot. Una de sus cartas más extrañas nos puede ser de utilidad. Es la número doce, cuya reducción numerológica nos da tres, que representa la interacción de la unidad y la dualidad: el colgado - la misma carta que la Madame Sosostris de The Waste Land (otro texto demencial) no puede ver. En esta carta encontramos a un joven que suspendido cuelga, cabeza abajo, de un tronco (o una picota de madera), al cual está amarrado uno de sus tobillos. Tiene las manos atadas a la espalda, la otra pierna doblada, y en algunas barajas aparece con un halo alrededor de la cabeza.

A veces a esta carta se le llama el sacrificio. Otras se le asocia con un estado de éxtasis trascendente, de quien ha tomado conciencia de las fuerzas antagónicas que actúan en él y que logra preservar un balance precario en el vacío, al renunciar a todo apoyo externo. Citemos un comentario interpretativo:

${ }^{19}$ D. DAY, op. cit., pp. 327-328. 
The Hanged Man illustrates one who has taken his life in his hands and cast himself head first into the depths. His action has not been foolhardy, however, for he hangs safely suspended by the knot of his own faith. The knot is sometimes depicted as being formed from the living branch of a tree: The World Tree, or Tree of Life that grows through every plane of the cosmos. The Hanged Man's enraptured face reveals that his sacrifice has not been in vain, and that he has his reward. His torture is transmuted into ecstasy. ${ }^{20}$

Con todos estos elementos, ahora estamos en posición de entender por qué Lowry le da tal importancia al número doce; cuál es el simbolismo que rodea al árbol al revés, el sustrato mitológico que circunda la novela, y el impulso trascendente que parece mover a Geoffrey. Lo que no encaja es la poca madurez y la casi nula conciencia del cónsul en lo que hace. $Y$ aquí es donde entra el alcohol. Lowry anota en el documento epistolar antes aludido: "In the Cabbala, the misuse of magical powers is compared to drunkenness or the misuse of wine, and termed, if I remember rightly, in Hebrew sod". ${ }^{21}$ Lowry no recordó bien como se verá más adelante, pero nos da una pista respecto al tipo de empresa (que confiere una "base mágica al mundo") en la que se ubica al cónsul, quien - como se recordará- aparece rodeado, en el capitulo 6, de libros esotéricos y tratados alquímicos. Para Lowry el mezcal tiene una naturaleza dual. Es una bebida ordinaria que se puede conseguir en cualquier cantina. Pero a su vez: "mescal is also a drug, taken in the form of buttons, and the transcending of its effects is one of the well-known ordeals that occultists have to go through. It would appear that the Consul has fuddledly come to confuse the two, and he is perhaps not far wrong". 22

Lowry confunde de nuevo los hechos al creer que el mezcal, en México, tiene un uso ritual y propiedades alucinógenas. Pero si pensamos por un instante en uno de los sinónimos de licor en lengua inglesa, "spirits", podremos entender a qué se quería referir nuestro autor. El alcohol embrutece pero también - parece sugerir la novela - a ratos ilumina.

Entre los intereses del Cónsul está la alquimia, y Jung ha demostrado que el alquimista -en sus denodados y reiterativos esfuerzos por degradar, purificar y transmutar las sustancias con las que trabajaba - intentaba transmutarse a sí mismo, buscando liberar el "espíritu" atrapado en la materia. El cónsul, Malcolm Lowrry parece decirnos, está involucrado, de manera harto equívoca, en una tentativa semejante. Y las constantes referencias a la selva dantesca, el Casino

\footnotetext{
${ }^{20}$ Alfred Douglas, The Tarot. Harmondsworth, Penguin, 1973, p. 81.

${ }^{21}$ H. BREIT y M. BONNER LOWRY, eds., op. cit., p. 71.

22 Idem.
} 
de la Selva o la búsqueda en el bosque parecen apuntar en esa dirección. O para citar de nuevo a Lowry: "On the surface Hugh and Yvonne are simply searching for the Consul, but such a search would have added meaning to anyone who knows anything of the Eleusinian mysteries, and the same esoteric idea of this kind of search also appears in Shakespeare's The Tempest" ${ }^{23}$ Éste parece ser el sentido profundo ("at a very sunk level of the book") de las vicisitudes por las que pasa nuestro cónsul. En la cábala, al último nivel de interpretación (equivalente al anagógico de la hermeneútica bíblica) se le denomina pardes o sod (misterio), el término al que Lowry aludió antes en su carta.

Under the Volcano es una novela enciclopédica como Ulysses, y como la obra de Joyce parece exhibir un alto grado de hipercodificación en términos intertextuales, intratextuales y referenciales, que permiten una multiplicidad de lecturas, de las cuales nos hemos referido en este ensayo a un sólo nivel: el mágico-trascendente. Para terminar pongamos un somero ejemplo de referenciabilidad. Uno de los signos ubicuos de la novela es la película estadounidense de estilo expresionista Las manos de Orlac, que Lowry concibe como una metáfora de la situación mundial que circunda a la obra. Su discurso fílmico se inscribe dentro del género de terror, pero también es una película de amor; y de hecho su título original es Mad Love (1935), por lo que podría ser una metáfora de quien, a lo largo de la novela, ha presentado como divisa que "No se puede vivir sin amar". Durante el paseo a caballo Hugh la menciona: "It's all about a pianist who has a sense of guilt because his hands are a murderer's". ${ }^{24}$ Pero resulta que la esposa del pianista es una actriz —a quien admira y ama el doctor trasnochado que realiza el transplante-que responde ni más ni menos al nombre de Yvonne.

El lector ideal de Under the Volcano, siguiendo el esquema circular del autor, querría volver al capítulo inicial; y allí se encontraría las coordenadas geográficas de Quauhnahuac que lo sitúan en el mismo paralelo que Hawaii y el golfo de Bengala, y, tal vez, entonces recordaría (según el modelo de autorreflexividad propuesto por Joseph Frank) que son los lugares donde nacieron Yvonne y nuestro fraternal Cónsul. ${ }^{25}$

${ }^{23}$ Ibid., p. 83.

${ }^{24}$ M. LOWRY, op. cit., p. 114.

${ }^{25}$ Para un enfoque de este tipo véase Victor DOYEN, "Elements Towards a Spatial Reading of Malcom Lowry's Under the Volcano", en English Studies, 50, núm. 1. 1960, pp. 65-74. 